\title{
Luonnonlakoissa on potentiaalia viljelyyn
}

Ville Korpelainen ${ }^{1)}$, Kalle Hoppula ${ }^{1)}$ ja Heli Pirinen ${ }^{2)}$

1) MTT Sotkamo, Kipinäntie 16,88600 Sotkamo, etunimi.sukunimi@mtt.fi

2)ProAgria Kainuu, Osmonkatu 9,87100Kajaani, heli.pirinen@proagria.fi

\section{Tiivistelmä}

Kainuussa on kehitetty lakan (Rubus chamaemorus L.) viljelyä vuodesta 1999. Osana kehitystyötä MTT Sotkamoon on kerätty laaja kokoelma lakan luonnonkantoja, joiden kasvua ja sadontuottoa on seurattu kantavalintakokeessa vuodesta 2005.

Lakan viljelyn eräinä ongelmina ovat viljellyn marjan korkeat tuotantokustannukset ja erityisesti matalahko satotaso ja poiminnan kalleus (Hoppula ym. 2007). Lakan viljelyssä käytetään nykyisin pääosin norjalaisia kaksikotisia lajikkeita. Kaksikotisia lakkoja viljeltäessä pölytys ei ole aina onnistunut ja sadot ovat jääneet pieniksi. Pölytykseen liittyvien ongelmien ehkäisemiseksi on lisätty kotimaisen kaksineuvoisen lajikkeen 'Nyby' taimituotantoa. 'Nybyn' heikkous on kuitenkin pieni marjakoko.

Kantavalintakokeen tavoitteena oli vertailla suurta määrää eri alkuperää olevia lakkakantoja ja valita näistä lupaavimmat kannat jatkotutkimuksiin ja edelleen valikoida viljelyyn ominaisuuksiltaan nykyisiä viljelylajikkeita parempia kantoja.

Koe toteutettiin kerranteettomana esivalintakokeena vuosina 2005-2007. Lakat viljeltiin puhtaassa vaaleassa rahkaturpeessa maahan upotetuissa astioissa ja niistä seurattiin kasvua, kukintaa ja sadontuottoa. Kaikkiaan vertailtavana oli 79 erilaista Kainuusta kerättyä lakan luonnonkantaa ja kaksineuvoinen lajike 'Nyby'.

Kokeessa oli 20 emikantaa, joiden marjakoko on nykyisiä viljelylajikkeita suurempi. Näistä kaksi kantaa oli suurisatoisia satotason ollessa yli $200 \mathrm{~g} / \mathrm{m}^{2}$. Kahdella kannalla marjakoko oli erittäin suuri, kannalla E9 marjan keskipaino oli 4 grammaa ja E10 jopa 5,4 grammaa. Hedekannoissa oli kuusi runsaasti ja pitkään kukkivaa kantaa. Kaksineuvoisista kannoista K3 oli suurempimarjainen kuin 'Nyby' marjan keskipainon ollessa 1,6 g/kpl ja E1 oli 'Nybytä' satoisampi.

Luonnonkannoissa on potentiaalia nykyisiä viljelylajikkeita paremmiksi viljelylajikkeiksi. Kantojen valinta vaatii kuitenkin vielä tarkempia tutkimuksia ja useamman vuoden seurannan, jotta parhaat kannat saadaan seulottua lisättäväksi viljelyyn. Parhaista kannoista on perustettu uusi valintakoe MTT Sotkamoon.

Asiasanat: lakka, Rubus chamaemorus, lajikkeet 


\section{Johdanto}

Kainuussa on kehitetty lakan (Rubus chamaemorus L.) viljelyä vuodesta 1999 usean toimijan yhteistyön voimin. Osana kehitystyötä MTT Sotkamoon on kerätty laaja kokoelma lakan luonnonkantoja, joiden kasvua ja sadontuottoa on seurattu kantavalintakokeessa vuodesta 2005 vuoteen 2007. Koe tehtiin osana Euregio Karelia -osarahoitteista hanketta "Erikoismarjat markkinoille". Hanketta hallinnoi ProAgria Kainuu.

Lakan viljelyn eräinä ongelmina ovat viljellyn marjan korkeat tuotantokustannukset ja erityisesti matalahko satotaso ja poiminnan kalleus (Hoppula ym. 2007). Lakan viljelyssä käytetään nykyisin pääosin norjalaisia kaksikotisia lajikkeita. Näistä 'Fjellgull' on todettu manner-Suomen olosuhteissa satoisimmaksi (Hoppula ym. 2006).

Kaksikotisia lakkoja viljeltäessä pölytys ei ole aina onnistunut ja sadot ovat jääneet pieniksi. Pölytykseen liittyvien ongelmien ehkäisemiseksi on lisätty kotimaisen kaksineuvoisen lajikkeen 'Nyby' taimituotantoa. 'Nybyn' heikkous on kuitenkin pienehkö marjakoko.

Nykyisiä lajikkeita sadoltaan ja marjakooltaan suurempi emilajike voisi alentaa lakan tuotantokustannusta merkittävästi. Samoin kaksikotisia lakkoja viljeltäessä runsaasti ja pitkään kukkiva hedelajike voisi parantaa satotasoa pölyttymistä varmistamalla.

Kantavalintakokeen tavoitteena oli vertailla suurta määrää eri alkuperää olevia lakkakantoja kontrolloidusti ja saada tuloksia, joiden perusteella valita näistä lupaavimmat kannat jatkotutkimuksiin ja edelleen valikoida viljelyyn ominaisuuksiltaan nykyisiä viljelylajikkeita parempia kantoja.

\section{Aineisto ja menetelmät}

\section{Lakkakannat}

Kokeessa oli vertailtavana alun perin 80 eri kantaa (ml. 'Nyby'). Kannoista kuusi menehtyi istutusvuonna. Jäljelle jääneistä 74 kannasta 47 oli emikukallisia, 12 hedekukallisia, neljä kaksineuvoista kantaa (ml. 'Nyby'), kolme kantaa joissa havaittiin emi- ja hedekukkia ja kahdeksan sukupuoleltaan tuntematonta kantaa. Vertaillut kannat oli kerätty vuonna 2003 eri puolilta Kainuuta lukuun ottamatta lajiketta 'Nyby', joka oli saatu MTT Laukaan tutkimus- ja valiotaimiasemalta.

\section{Viljely}

Koe toteutettiin kerranteettomana esivalintakokeena MTT Sotkamon tutkimusasemalla $\left(64^{\circ} 6^{\prime} \mathrm{P}, 28^{\circ}\right.$ $20^{\prime}$ I, 157 m merenpinnan yläpuolella). Taimet istutettiin kesäkuussa 2005 ja viljeltiin vaaleassa rahkaturpeessa sisähalkaisijaltaan n. $52 \mathrm{~cm}: n$ muoviputkesta tehdyissä $58 \mathrm{~cm}$ pituisissa hitsattupohjaisissa astioissa (valmistaja M-Plast, Kaavi). Astiat oli upotettu maahan $53 \mathrm{~cm}$ syvyyteen. Koeastian pinta-ala oli n. $0,212 \mathrm{~m}^{2}$, kasvualustan syvyys $53 \mathrm{~cm}$ ja tilavuus siten 112 litraa. Astioiden pohjalla oli salaojaputki, joka sääti veden pinnan $-30 \mathrm{~cm}: n$ tasolle kasvualustan pinnasta. Salaojaputki oli peitetty soralla, loput astiasta kasvualustana käytetyllä lannoittamattomalla ja kalkitsemattomalla turpeella. Astioita kasteltiin tippukastelulla tarpeen mukaan. Koekentällä ei käytetty kemiallista kasvinsuojelua ja rikkakasvit kitkettiin pois käsin niiden havaitsemisen jälkeen.

\section{Havainnot}

Kokeelta tehtiin kasvu-, kukinta- ja satohavaintoja kokeen aikana. Vuonna 2005 laskettiin lehtien lukumäärä, kukat ja sato. Vuonna 2006 laskettiin lehtien lukumäärä, lehtien peittävyys kolmena eri ajankohtana sekä kukkasilmujen lukumäärä. Kukinnan alun aikainen halla kuitenkin tuhosi kukat, eikä kukinta- tai satotuloksia saatu. Vuonna 2007 laskettiin versojen määrä, kukkien määrä seitsemänä eri päivänä kukinnan aikaan, kukkasilmujen kokonaismäärä sekä sato (massa ja kappalemäärä). Kokeen lopuksi maaversot kaivettiin ylös ja punnittiin.

\section{Tulokset ja tulosten tarkastelu}

Kokeesta valittiin 29 lupaavinta kantaa jatkotutkimuksiin: 20 emikantaa (nimetty E1-E20), kuusi hedekantaa (H1-H6) ja kolme kaksineuvoista kantaa (K1, K3 ja K4). Tässä raportissa käsitellään tuloksia vain näiden kantojen osalta. Kantojen valinnassa hyödynnettiin satotuloksia vuosilta 2005 ja 2007, mutta tässä esitetävät tulokset ovat pääosin vuodelta 2007, koska tällöin kannat olivat jo ehtineet kasvaa ja tulokset ovat istutusvuotta edustavammat. Valintaperusteina käytettiin emikannoilla satomäärää ja marjakokoa, hedekannoilla kukkien kokonaismäärää ja kukinta-ajan pituutta. Kaksineuvoisista kannoista jatkotutkimuksiin otettiin kaikki. 
Tuloksista erottuu hedekantojen voimakkaampi kasvu niiden emi- ja kaksineuvoisia kantoja keskimäärin suuremmassa versojen ja maarönsyn määrässä (Taulukko 1). Kukkien ja raakileiden suhteesta laskettuna emikannat pölyttyivät kaksineuvoisia paremmin: emikannoilla keskimäärin $85 \% \mathrm{ku}$ kista kehittyi raakileiksi, kaksineuvoisilla vain $72 \%$. Pienen otoskoon ja koeasetelman vuoksi tulos ei ole luotettava, mutta kuitenkin kiinnostava, koska kaksineuvoisia kantoja on suositeltu viljeltäväksi nimen omaan siksi, että niillä pölyttymisen on oletettu olevan yksineuvoisia varmempaa.

Taulukko 1. Lakkakantojen kasvu-, kukinta- ja satotulokset vuodelta 2007. E1-E20 ovat emi-, H1-H6 hede- ja K1-K4 kaksineuvoisia kantoja. ka = kunkin ryhmän keskiarvo. Tähdellä merkityt tulokset ovat vuodelta 2005. Astiaa kohden ilmoitetut arvot saa muutettua neliömetrille jakamalla ne astian pinta-alalla $0,212 \mathrm{~m}^{2}$.

\begin{tabular}{|c|c|c|c|c|c|c|c|c|}
\hline Kanta & $\begin{array}{l}\text { Versot, } \\
\mathrm{kpl} / \text { astia }\end{array}$ & $\begin{array}{c}\text { Maarönsy, } \\
\text { g/astia }\end{array}$ & $\begin{array}{c}\text { Kukinta- } \\
\text { aika }\end{array}$ & $\begin{array}{l}\text { Kukat, } \\
\mathrm{kpl} / \text { astia }\end{array}$ & $\begin{array}{c}\text { Raakileet, } \\
\text { kpl/astia }\end{array}$ & $\begin{array}{c}\text { Kauppake } \\
\text { kpl/astia }\end{array}$ & $\begin{array}{l}\text { en sato, } \\
\text { g/astia }\end{array}$ & $\begin{array}{c}\text { Marjakoko } \\
\mathrm{g} / \mathrm{kpl}\end{array}$ \\
\hline E1 & 5 & 34 & $27.5 .-3.6$ & 6 & 5 & 1 & 1,6 & 1,6 \\
\hline E2 & 10 & 20 & 31.5. - 4.6. & 5 & 3 & 3 & 5,9 & 2,0 \\
\hline E3 & 90 & 298 & 28.5. - 4.6. & 19 & 16 & 8 & 12,9 & 1,6 \\
\hline E4 & 20 & 80 & 31.5. - 3.6. & 16 & 13 & 4 & 10,6 & 2,7 \\
\hline E5 & 27 & 45 & 29.5. - 4.6. & 14 & 12 & 8 & 14,6 & 1,8 \\
\hline E6 & 80 & 462 & 28.5. - 4.6. & 10 & 9 & 2 & 6,1 & 3,1 \\
\hline E7 & 17 & 61 & 28.5. - 1.6. & 3 & 3 & 2 & 4,1 & 2,1 \\
\hline E8 & 35 & 154 & 29.5. - 1.6. & 8 & 6 & 6 & 16,8 & 2,8 \\
\hline E9 & 30 & 96 & 28.5. - 4.6. & 25 & 24 & 11 & 43,9 & 4,0 \\
\hline E10 & 23 & 86 & 29.5. - 3.6. & 5 & 3 & 2 & 10,8 & 5,4 \\
\hline E11 & 35 & 170 & 26.5. - 4.6. & 4 & 3 & 1 & 1,7 & 1,7 \\
\hline E12 & 132 & 437 & 26.5. - 4.6. & 60 & 53 & 33 & 51,2 & 1,6 \\
\hline E13 & 33 & 146 & 26.5. - 4.6. & 17 & 17 & 7 & 16,2 & 2,3 \\
\hline E14 & 10 & 42 & 28.5. - 4.6. & & & $3 *$ & $7,2 *$ & $2,4 *$ \\
\hline E15 & 19 & 60 & 29.5. - 1.6. & 2 & 1 & 1 & 2,5 & 2,5 \\
\hline E16 & 50 & 286 & 28.5. - 4.6. & 14 & 14 & 6 & 11,0 & 1,8 \\
\hline E17 & 37 & 110 & 26.5. - 1.6. & 9 & 6 & 3 & 5,5 & 1,8 \\
\hline E18 & 63 & 363 & 28.5. - 4.6. & 15 & 14 & 5 & 13,6 & 2,7 \\
\hline E19 & 9 & 90 & 26.5. - 3.6. & 9 & 8 & 6 & 15,5 & 2,6 \\
\hline E20 & 35 & 208 & 29.5. - 6.6. & 11 & 5 & 2 & 5,3 & 2,6 \\
\hline ka & 38 & 162,4 & & 13,3 & 11,3 & 5,8 & 13,1 & 2,5 \\
\hline H1 & 36 & 247 & 27.5. - 4.6. & 20 & & & & \\
\hline $\mathrm{H} 2$ & 231 & 696 & 26.5. - 6.6. & 48 & & & & \\
\hline $\mathrm{H} 3$ & 76 & 442 & 26.5. - 4.6. & 17 & & & & \\
\hline $\mathrm{H} 4$ & 150 & 654 & 26.5. - 4.6. & 29 & & & & \\
\hline H5 & 147 & 541 & 26.5. - 6.6. & 34 & & & & \\
\hline H6 & 155 & 522 & 27.5. - 6.6. & 23 & & & & \\
\hline ka & 132,5 & 517 & & 28,5 & & & & \\
\hline K1 & 70 & 216 & 28.5. - 4.6. & 20 & 16 & 10 & 9,1 & 0,9 \\
\hline 'Nyby' & 111 & 296 & 29.5. - 6.6. & 18 & 12 & 6 & 7,3 & 1,2 \\
\hline K3 & 15 & 98 & 30.5. - 4.6. & 9 & 5 & 2 & 3,2 & 1,6 \\
\hline K4 & 22 & 130 & 3.6. - 4.6. & 2 & 2 & 1 & 0,5 & 0,5 \\
\hline ka & 54,5 & 185 & & 12,3 & 8,8 & 4,8 & 5,0 & 1,1 \\
\hline
\end{tabular}

\section{Emikannat}

Kokeessa oli kaksi emikantaa, joista saatiin suurempi sato vuonna 2007 kuin 'Fjellgullista' lajikekokeessa vuonna 2004 (Hoppula ym. 2006). Satomäärät olivat suurimmillaan 51 ja 44 grammaa astiaa kohden vastaten noin 240 ja 207 gramman neliömetrisatoja (Taulukko 1). Kukinnan ja raakilemäärän perusteella potentiaalisesti suurempisatoisia kantoja oli enemmänkin, mutta pääosin hillanälvikkään ja lintujen aiheuttamien satotappioiden vuoksi marjasato jäi monessa astiassa pieneksi (Taulukko 1).

Suurimarjaisia emikantoja oli $20 \mathrm{kpl}$. Suurimarjaisina voidaan pitää keskipainoltaan yli $1,5 \mathrm{~g}$ painoisia marjoja tuottavia kantoja, koska aiemmissa kokeissa 'Fjellgullin' ja 'Fjordgullin' keskimää- 
räinen marjan paino on ollut noin 1,4 g (Hoppula ym. 2006). Näistä yhdeksällä kannalla marjan keskipaino oli vähintään 2,5 g ja edelleen kahdella kannalla yli 3,5 g (Taulukko 1).

\section{Kaksineuvoiset kannat}

Kaksineuvoisista lakoista kanta K1 oli satoisampi (sato 9,1 g/astia), mutta marjakooltaan (0,92 g/marja) pienempi kuin 'Nyby', jonka sato oli 7,3 g/astia ja marjan keskipaino 1,2 g/marja (Taulukko 1). Kanta K3 puolestaan oli suurempimarjainen (1,6 g/marja) kuin 'Nyby', mutta tuotti tätä pienemmän sadon, vain 3,15 g/astia (Taulukko 1).

\section{Hedekannat}

Hedekannoissa oli kuusi kantaa, jotka kukkivat pitkään, yli viikon ajan, ja runsaasti (keskimäärin yli 20 kukkaa/astia). Runsaimmin kukkivalla kannalla H2 kukkia oli noin $180 \mathrm{kpl} / \mathrm{m}^{2}$. Hedekasvit kasvattivat keskimäärin moninkertaisesti maarönsyä emi- ja kaksineuvoisiin kantoihin nähden (Taulukko 1).

\section{Johtopäätökset}

Luonnonkannoissa on potentiaalia nykyisiä viljelylajikkeita paremmiksi viljelylajikkeiksi. Kantojen valinta vaatii kuitenkin vielä tarkempia tutkimuksia ja useamman vuoden seurannan, jotta parhaat kannat saadaan seulottua lisättäväksi viljelyyn. Tämän kokeen perusteella ei vielä tehty suurta karsintaa, vaan jatkotutkimuksiin valittiin kaikki vähääkään lupaavat kannat. Jatkotutkimuksissa tulisi seurata edelleen kantojen kasvuvoimakkuutta, kukinnan ajoittumista ja määrää, kukka-verso -suhdetta, sadon määrää ja marjakokoa.

\section{Kirjallisuus}

Hoppula, K., Kajalo, M. \& Pirinen, H. 2007. The price of the cultivated cloudberry is high. NJF Report 3(2), 413-414.

Hoppula, K., Pirinen, H., Miettinen, E. 2006. Lakasta viljelykasvi?. In: Toim. Anneli Hopponen. Maataloustieteen Päivät 2006, 11.-12.1.2006 Viikki, Helsinki [: esitelmät ja posterit]. Suomen maataloustieteellisen seuran tiedote 21: 6 s. http://www.smts.fi/pos06/0107.pdf Julkaistu 9.1.2006 